\title{
Pengaruh Pupuk Daun "Organik" terhadap Komposisi Kimiawi dan Kecernaan Rumput Gajah (Pennisetum purpureum CV. Hawaii)
}

\author{
Badat Muwakhid, Usman Ali \\ Fakultas Peternakan, Universitas Islam Malang \\ Jl. Mayjen Haryono No.193, Dinoyo, Kota Malang, Jawa Timur 65144 \\ *Email korespondensi: badatmalang@gmail.com
}

(Diterima 12-01-2020; disetujui 05-09-2020)

\begin{abstract}
ABSTRAK
Pupuk cair yang memanfaatkan bahan organik seperti urin yang difermentasi dan zat pengatur tumbuh dapat memberikan tambahan unsur hara yang diperlukan rumput untuk tumbuh. Upaya perbaikan kualitas rumput gajah dapat dilakukan dengan pemberian pupuk daun "organik", dengan memperhatikan dosis pemberiannya. Tujuan penelitian ini adalah menentukan dosis pemberian pupuk daun "organik" yang tepat untuk mendapatkan kualitas hijauan yang maksimal. Materi penelitian ini meliputi pupuk daun "organik" dan bibit rumput gajah dalam keadaan pols, dengan rata-rata panjang perpols adalah $10 \mathrm{~cm}$. Penelitian menggunakan metode percobaan dengan menggunakan rancangan acak lengkap (RAL) dengan 4 perlakuan dan masing-masing perlakuan menggunakan 5 kali ulangan. Perlakuan yang diberikan adalah P0 (kontrol), P1 (5\% pupuk daun "organik"), P2 (10\% pupuk daun "organik") dan P3 (15\% pupuk daun "organik"). Hasil penelitian ini menunjukkan bahwa perlakuan pemberian dosis pupuk daun "organik" yang berbeda memperikan pengaruh yang sangat nyata $(\mathrm{P}<0,01)$ terhadap kandungan Neutral Detergent Fiber (NDF), Acid Detergent Fiber (ADF), selulosa, hemiselulosa, lignin, kecernaan in vitro bahan kering dan kecernaan in vitro bahan organik rumput gajah. Berdasarkan penelitian ini pemberian dosis 15\% pupuk daun "organik" menunjukkan hasil yang paling baik.
\end{abstract}

Kata kunci: komposisi kimiawi. pupuk daun organik, rumput gajah, , kecernaan

\begin{abstract}
Liquid fertilizers using organic ingredients such as bio urine can provide additional nutrients to optimize the grow of grass. Efforts to improve the quality of elephant grass can be done by providing this organic fertilizer by calculating the dosage given. The purpose of this study was to determine the appropriate dosage of "organic" leaf fertilizers to obtain maximum forage quality. The research material used were "organic" leaf fertilizers and elephant grass seedlings in a state of pols, with an average length of each pols is $10 \mathrm{~cm}$. The research method is experiment using a completely randomized design (CRD) which consisted of 4 treatments and 5 repetitions. The treatments given in this study were P0 (control), P1 (5\% "organic" leaf fertilizers), P2 (10\% "organic" leaf fertilizers) and P3 (15\% "organic" leaf fertilizers). The results of this study indicate that the implementation of different dosages of "organic" leaf fertilizers had significant effect $(\mathrm{P}<0.01)$ on the content of Neutral Detergent Fiber (NDF), Acid Detergent Fiber (ADF), cellulose, hemicellulose, lignin, dry matter digestibility (in vitro) and organic matter digestibility (in vitro) of elephant grass. Based on this study, $15 \%$ dose of "organic" leaf fertilizers showed the best results.
\end{abstract}

Keywords: chemical compounds, digestibility, elephant grass, organic leaf fertilizers

\section{PENDAHULUAN}

Pupuk organik yang berasal dari hasil pembusukan bahan organik biasanya mengandung lebih dari satu unsur hara. Pupuk cair yang memanfaatkan bahan organik seperti urin yang difermentasi dan zat pengatur tumbuh dapat memberikan tambahan unsur hara yang diperlukan rumput untuk tumbuh. Urin yang difermentasi yang dimanfaatkan menjadi pupuk biasanya ditambah bahan lain untuk mengurangi bau yang ditimbulkan (Mappanganro et al., 2018). Urin yang difermentasi ditambah dengan empon-empon, disamping medapat mengurangi bau yang dihasilkan oleh 
pembusukan urin, juga memiliki sifat penolak hama atau penyakit tanaman. Urin yang difermentasi dapat diaplikasikan pada tanaman karena mengandung hormon auksin yang berpengaruh terhadap perkembangan sel dan pembentukan kalus. Kandungan urin sapi terfermentasi menurut Rosniawaty, et al. (2015) terdiri atas C-organik $0,74 \%$, $\mathrm{N}$ total $1,79 \%, \mathrm{P}_{2} \mathrm{O}_{5} 0,005 \%, \mathrm{~K}_{2} \mathrm{O} 1,68 \%$, dan $\mathrm{pH} 8,74$.

Penggunaan pupuk untuk meningkatkan produksi tanaman sudah dilakukan sejak dahulu. Pemberian pupuk dapat dilakukan dengan metode penyemprotan pada daun sehingga lebih efektif. Rumput gajah yang telah terkenal digunakan sebagai hijauan pakan ternak juga dapat memanfaatkan adanya pupuk cair untuk meningkatkan kualitasnya. Kualitas rumput gajah dapat ditinjau dari segi kandungan fraksi serat dan kecernaannya. Hijauan dengan fraksi serat yang tinggi akan menyebabkan kurangnya degradabilitas pakan. Nilai kecernaan pakan juga penting untuk diperhatikan karena pakan dengan kualitas tinggi akan memberkan nilai kecernaan yang tinggi pula. Berdasarkan hasil penelitian Setiyaningsih, et al. (2012) dosis pemberian pupuk organik cair ternyata memberikan efek yang nyata terhadap nilai kecernaan bahan kering dan kecernaan bahan organik pada hijauan $D$. cinereum. Pada penelitian lain oleh Muhakka et al. (2014) dosis pemberian pupuk cair pada rumput gajah Taiwan tidak memberikan perbedaan yang nyata pada kadar NDF dan ADF nya, meskipun begitu secara numerik terlihat ada perbedaan kadar NDF dan ADF pada masing-masing perlakuan dosis pemberian pupuk cair.

Penelitian untuk mengetahui berapa dosis pemberian pupuk yang tepat untuk rumput gajah penting dilakukan untuk mendapatkan rumput dengan kualitas baik. Penelitian ini akan dilakukan untuk menentukan efek pemberian pupuk daun "organik" dengan beberapa dosis terhadap komposisi kimiawi dan kecernaan in vitro rumput gajah. Tujuan penelitian ini adalah mendapatkan dosis pemberian pupuk daun "organik" terbaik pada rumput gajah.

\section{MATERI DAN METODE}

\section{Materi}

Materi yang digunakan pada penelitian ini meliputi pupuk daun "organik" dan bibit rumput gajah dalam keadaan pols, dengan rata-rata panjang perpols adalah $10 \mathrm{~cm}$.

\section{Pembuatan pupuk}

Pembuatan pupuk daun "organik" terdiri atas 2 tahapan, yaitu tahap fermentasi urin dan tahap pembuatan zat pengatur tumbuh. Tahapan fermentasi urin dilakukan mulai dari penyiapan urin dari sapi perah friesian holstein $(\mathrm{FH})$ dan menyaring isi rumen. Empon-empon yang digunakan terdiri dari kunyit (Curcuma longa), temu ireng, (Curcuma seroginosa), temu lawak (Curcuma zanthorrhiza) yang dicuci, ditumbuk, kemudian diperas, masing masing daun pahitan (Tithonia diversifolia) dan daun lamtoro (Leucaena leucocephala) ditumbuk lalu diperas, molases dan air cucian beras. Urin yang digunakan adalah dua puluh bagian, empon-empon dua bagian, daun paitan satu bagian, daun lamtoro satu bagian, molasis tiga bagian, air cucian beras satu bagian dan isi rumen lima bagian kemudian dcampur lalu diaduk hingga merata. Larutan yang dihasilkan disimpan dalam wadah tertutup hingga tujuh hari.

\section{Pembuatan zat pengatur tumbuh}

Pembuatan zat pengatur tumbuh dilakukan melalui beberapa tahapan mulai dari penyiapan bonggol pisang, rebung bambu, pucuk daun rumput gajah, dan kecambah yang kemudian ditumbuk, diperas dan disaring. Gula merah diberi air sepertiga bagian lalu direbus hingga mencair kemudian didinginkan dan disaring. Air kelapa dan isi rumen disaring, satu bagian dari masing-masing hasil penyaringan bonggol pisang, rebung bambu, pucuk daun rumput gajah, kecambah, ditambah dengan satu bagian hasil penyaringan gula, di tambah satu bagian air kelapa, ditambah dua bagian hasil penyaringan isi rumen, kemudian di-aduk hingga merata, setelah itu ditutup hingga empat hari, dan tahap terakhir adalah penyaringan.

Pupuk daun "organik" tersusun atas dua puluh bagian urin terfermentasi ditambah satu bagian zat pengatur tumbuh. Pemupukan disemprotkan $100 \mathrm{ml}$ pada setiap rumpun rumput gajah, level dosis pemupukan ditetapkan dalam prosentase pupuk "organik" dalam air. Pemupukan dilakukan sebanyak 3 kali yakitu pada hari ke-10, 20 dan 30 setelah dipotong.

\section{Metode}

Metode penelitian ini adalah percobaan lapang dengan menggunakan Rancangan Acak Lengkap (RAL) dengan empat perlakuan dan masing-masing perlakuan diulang sebanyak 5 kali, adapun perlakuan yang diberikan yaitu:

P0 : perlakuan kontrol tanpa penyemprotan pupuk daun "organik" 
P1 : penyemptotan pupuk daun "organik" dosis $5 \%$

P2 : penyemptotan pupuk daun "organik" dosis $10 \%$

P3 : penyemptotan pupuk daun "organik" dosis $15 \%$

Prosedur penelitian ini dimulai dengan persiapan lahan, tanah yang akan ditanami rumput gajah dibajak terlebih dahulu sebanyak 2 kali lalu digemburkan. Pemilihan rumput gajah untuk bibit terpilih berasal dari varietas yang sama. Penanaman bibit rumput gajah menggunakan sistem pols, pols rumput dimasuk-kan ke dalam tanah yang telah dilubangi sedalam 7-10 cm, lalu ditutup dengan tanah, jarak tanam antar baris $70 \mathrm{~cm}$ dan jarak tanam dalam baris $50 \mathrm{~cm}$, setiap lubang diberi tiga batang rumput gajah. Sebelum mulai diberi perlakuan pada tanaman, terlebih dulu dilakukan penyulaman. Pengairan dilakukan setiap tiga hari sekali dengan cara dialiri air sampai menggenang, lalu air dibuang hingga tuntas. Perawatan tanaman seperti pembersihan gulma dilakukan seminggu sekali. Kegiatan untuk mempersiapkan pemberian perlakuan, rumput ditanam hingga umur 40 hari, kemudian dipotong dengan tinggi pemotongan 3 $\mathrm{cm}$ dari tanah, setelah 10 hari pemotongan dan rumput telah tumbuh kembali, perlakuan penyemprotan pupuk diberikan. Fase pemanenan: rumput gajah dilakukan pada usia 40 hari dengan tinggi pemotongan $3 \mathrm{~cm}$ dari tanah, selanjutnya ditimbang, kemudian dianalisa sesuai dengan kebutuhan.

\section{Variabel penelitian}

Variabel yang diamati pada penelitian ini meliputi pengukuran Neutral Detergent Fiber (NDF), Acid Detergent Fiber (ADF), selulosa, hemiselulosa dan lignin menggunakan metode Van Soest (1977), sedangkan pengukuran kecernaan secara in vitro menggunakan metode Tilley and Terry (Tilley \& Terry, 1963).

\section{Analisa data}

Data yang diperoleh dianalisa menggunakan Analisa Ragam dan jika menunjukkan pengaruh nyata dilanjutkan dengan uji Beda Nyata Terkecil (BNT).

\section{HASIL DAN PEMBAHASAN}

\section{Komposisi Kimiawi pada Fraksi Serat}

Hasil penelitian terhadap komposisi kimiawi pada fraksi serat rumput gajah dengan beberapa perlakuan dosis penyemprotan pupuk daun "organik" tersaji pada Tabel 1.
Tabel 1. Komposisi kimiawi pada fraksi serat rumput gajah.

\begin{tabular}{lcccc}
\hline \multicolumn{1}{c}{ Kandungan } & $\mathrm{P} 0$ & $\mathrm{P} 1$ & $\mathrm{P} 2$ & $\mathrm{P} 3$ \\
\hline $\mathrm{NDF}(\%)$ & $62,14^{\mathrm{C}}$ & $55,91^{\mathrm{B}}$ & $53,93^{\mathrm{A}}$ & $53,10^{\mathrm{A}}$ \\
$\mathrm{ADF}(\%)$ & $40,71^{\mathrm{D}}$ & $38,37^{\mathrm{C}}$ & $37,79^{\mathrm{B}}$ & $37,18^{\mathrm{A}}$ \\
Selulosa (\%) & $41,22^{\mathrm{D}}$ & $39,55^{\mathrm{C}}$ & $38,58^{\mathrm{B}}$ & $37,54^{\mathrm{A}}$ \\
Hemiselulosa \%) & $24,77^{\mathrm{C}}$ & $19,13^{\mathrm{B}}$ & $18,83^{\mathrm{B}}$ & $17,34^{\mathrm{A}}$ \\
Lignin (\%) & $6,95^{\mathrm{C}}$ & $5,48^{\mathrm{B}}$ & $5,22^{\mathrm{B}}$ & $4,47^{\mathrm{A}}$ \\
\hline Keterangan: & Superskrip & (A-D) yang berbeda pada baris \\
& yang sama menunjukkan adanya per- \\
& bedaan yang sangat nyata (P<0,01); NDF \\
& (Neutral Detergent Fiber); ADF (Acid \\
& Detergent Fiber)
\end{tabular}

Kandungan NDF dan ADF suatu hijauan menurut Wahyono et al. (2019) berkorelasi dengan tingkat kecernaan hijauan tersebut. Kandungan NDF dan ADF rumput gajah pada penelitian ini dilaporkan memiliki perbedaan yang sangat nyata $(\mathrm{P}<0,01)$ antar perlakuan yang diberikan. Pemberian pupuk daun "organik" cenderung menurunkan kandungan NDF dan ADF rumput gajah. Penurunan kandungan NDF dan ADF terendah ditunjukkan perlakuan kontrol sedangkan penurunan yang tertinggi ada pada dosis penyemprotan pupuk daun "organik" $15 \%$. Proses fotosintesis berlangsung semakin baik dengan adanya penambahan pupuk daun "organik" karena semakin banyak dan semakin luas permukaan daun. Menurut Soediyanto dan Hamadi (1997) adanya peningkatan aktivitas fotosintesis menyebabkan penipisan dinding sel dan ukuran sel menjadi besar, serat pun akan menurun sehingga kandungan NDF dan ADF juga menurun. Hasil penelitian ini berbeda dengan hasil penelitian Sumolang et al. (2016) yang mana peningkatan dosis pupuk dapat mengakibatkan peningkatan kadar NDF rumput. Hal tersebut dikarenakan adanya peningkatan pada bahan kering rumput sehingga kandungan NDF nya juga meningkat. Menurut Jamilah et al. (2019) NDF merupakan indikator yang paling baik dari bulk dan sumber pakan yang masuk sedangkan ADF adalah indikator yang paling baik dari bahan yang dapat dihancurkan serta pengambilan energi.

Selulosa, hemiselulosa, dan lignin merupakan komponen penyusun dinding sel pada tanaman. Kandungan hemiselulosa, selulosa, dan lignin rumput gajah yang disemprot dengan pupuk cair "organik" pada penelitian ini menunjukkan pengaruh perlakuan yang sangat nyata $(\mathrm{P}<0,01)$. Ketiga variabel tersebut pada penelitian ini mengalami penurunan dengan adanya peningkatan dosis penyemprotan pupuk daun "organik" yang diberikan. Artinya kandungan selulosa, hemiselulosa dan lignin akan menurun seiring dengan peningkatan dosis pupuk daun "organik" yang diberikan. Kandungan selulosa, hemiselulosa dan 
lignin tertinggi ditunjukkan oleh perlakuan kontrol sedangkan yang terendah ditunjukkan oleh perlakuan P3 (dosis penyemprotan pupuk daun "organik" 15\%. Menurut Setyamidjaya (1986), pemberian $\mathrm{N}$ meningkatkan perbandingan protoplasma terhadap bahan dinding sel yang tipis, hal ini menyebabkan daun lebih banyak mengandung air dan kurang keras. Menipisnya dinding sel dapat menyebabkan komponen penyusunnya juga sedikit. Hasil penelitian menunjukkan kandungan hemiselulusa dan selulosa berbeda dengan penelitian yang telah dilakukan oleh Rauf, et al. (2017).

Hasil penelitian Rauf, et al. (2017) dengan menggunakan pupuk cair dengan tambahan bioaktivator buah mengkudu pada rumput Taiwan menunjukkan bahwa perlakuan perbedaan dosis penyemprotan pupuk tidak berpengaruh nyata $(\mathrm{P}>0,05)$ pada kandungan hemiselulosa rumput, sedangkan untuk kandungan selulosa perlakuan yang diberikan memberikan pengaruh yang nyata $(\mathrm{P}<0,05)$ namun dengan adanya peningkatan dosis pupuk cenderung meningkatkan kandungan selulosa. Sementara itu, hasil penelitian untuk variabel kandungan lignin pada penelitian ini sejalan dengan hasil penelitian Rauf et al. (2017) yang menunjukkan bahwa peningkatan dosis pupuk cair yang diberikan akan menurunkan kandungan lignin rumput. Menurut Jamilah, et al. (2019) hemiselulosa dan selulosa akan dicerna secara lambat oleh mikroba rumen, sedangkan lignin tidak dapat dicerna, fungsi lignin sebagai pengikat lintas antara sel satu dan lainnya. Selanjutnya menurut Susanti (2007) apabila proses lignifikasi pada rumput naik maka akan berdampak pada penurunan kecernaan suatu zat makanan.

\section{Kecernaan In Vitro Bahan Kering dan Bahan Organik}

Hasil penelitian terhadap kecernaan in vitro bahan kering dan bahan organik rumput gajah dengan beberapa perlakuan dosis penyemprotan pupuk daun "organik" tersaji pada Tabel 2.

Tabel 2. Kecernaan in vitro bahan kering dan organik rumput gajah

\begin{tabular}{|c|c|c|c|c|}
\hline Variabel & P0 & P1 & $\mathrm{P} 2$ & P3 \\
\hline Kc. BK (\%) & $51,53^{\mathrm{A}}$ & 55,9 & 58,1 & $59,02^{\mathrm{C}}$ \\
\hline Kc. BO (\%) & $38,53^{\mathrm{A}}$ & $43,84^{\mathrm{B}}$ & $47,01^{\mathrm{C}}$ & $47,24^{\mathrm{C}}$ \\
\hline \multicolumn{5}{|c|}{$\begin{aligned} & \text { Keterangan: } \text { Superskrip }{ }^{(\mathrm{A}-\mathrm{D})} \text { yang berbeda pada bari } \\
& \text { yang sama menunjukkan adany } \\
& \text { perbedaan yang sangat nyata }(\mathrm{P}<0,01) ; \mathrm{Kc} \\
& \text { BK (Kecernaan Bahan Kering); Kc. BC } \\
& \text { (Kecernaan Bahan Organik) }\end{aligned}$} \\
\hline
\end{tabular}

Kecernaan pakan ruminansia erat kaitannya dengan kandungan serat pakan tersebut. Kecernaan in vitro $\mathrm{BK}$ dan $\mathrm{BO}$ pada penelitian ini menunjukkan adanya perbedaan yang sangat nyata $(\mathrm{P}<0,01)$ antar perlakuan yang diberikan, terdapat peningkatan nilai kecernaan seiring dengan peningkatan dosis pupuk daun "organik" yang diberikan. Korelasi positif antara dosis pupuk dan tingkat kecernaan in vitro $\mathrm{BK}$ dan $\mathrm{BO}$ ini tidak lepas dari kandungan serat pada rumput gajah. Kandungan serat kasar serta selulosa, hemiselulosa dan lignin pada penelitian ini mengalami penurunan seiring dengan peningkatan dosis pupuk daun "organik" yang diberikan mengakibatkan adanya peningkatan kecernaan pada rumput gajah tersebut.

Hasil penelitian ini tidak sejalan dengan hasil penelitian yang dilakukan oleh Wibowo et al. (2017) yang menunjukkan bahwa pemupukan menggunakan pukan, bokashi dan urea (tanpa dan dengan inokulasi EM4) dalam waktu defoliasi yang berbeda tidak memberikan pengaruh yang nyata $(\mathrm{P}>0,05)$ terhadap kecernaan in vitro $\mathrm{BK}$ dan $\mathrm{BO}$ rumput gajah. Namun secara numerik terlihat bahwa penggunaan urea menghasilkan kecernaan in vitro yang lebih baik daripada pupuk organik, hal tersebut dikarenakan pupuk organik membutuhkan waktu yang lebih lama untuk terurai. Menurut Ifradi et al. (2012) ada korelasi positif antara kecernaan BK dan BO, hal ini karena bahan kering terdiri dari bahan organik dan anorganik. Menurut Novianti et al. (2014) beberapa faktor yang mempengaruhi kecernaan bahan kering yaitu jumlah pakan yang dikonsumsi, laju perjalanan makanan di dalam saluran pencernaan, dan jenis kandungan gizi pada pakan tersebut. Faktor lain yang mempengaruhi nilai kecernaan bahan kering adalah tingkat proporsi bahan pakan dalam ransum, komposisi kimia, tingkat protein, persentase lemak, dan mineral.

\section{KESIMPULAN}

Penggunaan pupuk daun "organik" berupa campuran urin terfermentasi dan zat pengatur tumbuh pada rumput gajah mampu menurunkan nilai fraksi serat serta meningkatkan kecernaan in vitro BK dan BO. Dosis pemberian daun "organik" terbaik yang dapat diberikan adalah $15 \%$.

\section{DAFTAR PUSTAKA}

Ifradi, Evitayani, A. Fariani, L. Warly, Suyitman, S. Yani \& Emikasmira. 2012. Pengaruh dosis pupuk N, P, dan K terhadap kecernaan secara in vitro rumput gajah (Pennisetum purpureum) cv. Taiwan yang di inokulasi CMA Glomus manihotis pada lahan bekas tambang batubara. Jurnal Peternakan Indonesia 14(1):279-285. 
Jamilah, S. Mulyani, \& Yusnaweti. 2019. Peranan pupuk organik cair terhadap kualitas hijauan pakan ternak (HPT) asal tanaman padi ratoon. Jurnal Agronida 5(2):59-69.

Mappanganro,R.,K. Kiramang,\& M.D. Kurniawan. 2018. Pemberian pupuk organik cair (urin sapi) terhadap tinggi Pennisetum purpureum cv. Mott. Junal Ilmu dan Industri Peternakan $4(1): 23-31$.

Muhakka, Riswandi, \& A. Irawan. 2014. Pengaruh pemberian pupuk cair terhadap kandungan $\mathrm{NDF}, \mathrm{ADF}$, kalium, dan magnesium pada rumput gajah Taiwan. Jurnal Peternakan Sriwijaya 3(1):47-54.

Novianti, J., B. P. Purwanto \& A. Atabany. 2014. Efisiensi produksi susu dan kecernaan rumput gajah (Pennisetum purpureum) pada sapi perah FH dengan pemberian ukuran potongan yang berbeda. Jurnal Ilmu Produksi dan Teknologi Hasil Peternakan 2 (1):224-230.

Purwawangsa, H. \& B. W. Putera. 2014. Pemanfaatan lahan tidur untuk penggemukan sapi. Risalah Kebijakan Pertanian dan Lingkungan 1 (2):92-96.

Rauf, J., R. Semaun, Fitriani, S. Hasan, \& B. Nohong. 2017. Kandungan ADF, NDF, hemiselulosa, selulosa, dan lignin rumput Taiwan (Pennisetum purpureum Schumach) pada berbagai level pupuk organik cair dengan penambahan bioaktivator buah mengkudu. Seminar Nasional Peternakan 3. Universitas Hasanuddin. Makassar.

Rosniawaty, S., R. Sudirja, \& H. Afrianto. 2015. Pemanfaatan urin kelinci dan urin sapi sebagai alternatif pupuk organik cair pada pembibitan kakao (Theobromacacao L.). Jurnal Kultivasi 14(1):32-36.

Setiyaningsih, K. D., M. Christiyanto, \& Sutarno. 2012. Kecernaan bahan kering dan bahan organik secara in vitro hijauan Desmodium cinereum pada berbagai dosis pupuk organik. Animal Agriculture Journal 1(2):51-63.
Setyamidjaja, D. 1986. Pupuk dan Pemupukan. Simplex. Jakarta.

Soedijanto \& Hamadi. 1997. Pupuk Kandang, Hijauan dan Kompos. Seri Peternakan Populer. Bumi Restu. Jakarta.

Sumolang, C.I.J., S.D. Anis, \& M.M. Telleng. 2016. Pengaruh pemupukan unsur hara makro N, $\mathrm{P}, \mathrm{K}$ terhadap potensi produksi NDF, ADF, kapasitas tampung rumput Brachiaria humidicola cv. Tully dan Pennisetum purpureum cv. Mott. Jurnal LPPM Bidang Sains dan Teknologi 3(2):75-82.

Susanti, S. 2007. Produksi dan kecernaan in-vitro rumput gajah pada berbagai imbangan pupuk nitrogen dan sulfur. Jurnal Buana Sains 7(2):151-156.

Tilley, J.M.A. \& R.A. Terry. 1963. A two stage technique for in the in vitro digestion of forage crops. J Grassland Soc 18:104.

Van Soest, P. J. 1977. Plant fiber and its role in herbivora nutrition. The Cornell Veterinarian 67(3):307-326.

Wahyono, T., E. Jatmiko, Firsoni, S.N.W. Hardani, \& E. Yunita. 2019. Evaluasi nutrien dan kecernaan in vitro beberapa spesies rumput lapangan tropis di Indonesia. Jurnal Sains Peternakan 17(2): 17-23.

Wibowo, T., D. R. Lukiwati \& Sumarsono. Nilai kecernaan in vitro bahan organik $(\mathrm{KcBo})$ dan bahan kering (KcBK) rumput gajah (Pennisetum purpureum Schumach \& Thonn) dengan pemupukan organik dan anorganik serta inokulasi mikroorganisme efektif (EM4). 2017. Jurnal Pengembangan Penyuluhan Pertanian 14(26):71-76. 